\title{
Efficacy of a 3 month training program on the jump-landing technique in jump-landing sports. Design of a cluster randomized controlled trial
}

\author{
Inne Aerts ${ }^{1}$, Elke Cumps', Evert Verhagen ${ }^{1,2}$, Romain Meeusen ${ }^{1 *}$
}

\begin{abstract}
Background: With the relatively high rate of injuries to the lower extremity due to jump-landing movement patterns and the accompanied high costs, there is need for determining potential preventive programs. A program on the intervention of jump-landing technique is possibly an important preventative measure since it appeared to reduce the incidence of lower extremity injuries. In real life situations, amateur sports lack the infrastructure and funds to have a sports physician or therapist permanently supervising such a program. Therefore the current prevention program is designed so that it could be implemented by coaches alone.

Objective: The objective of this randomized controlled trial is to evaluate the effect of a coach supervised intervention program targeting jump-landing technique on the incidence of lower extremity injuries.

Methods: Of the 110 Flemish teams of the elite division, 24 teams are included and equally randomized to two study groups. An equal selection of female and male teams with allocation to intervention and control group is obtained. The program is a modification of other prevention programs previously proven to be effective. All exercises in the current program are adjusted so that a more progressive development in the exercise is presented. Both the control and intervention group continue with their normal training routine, while the intervention group carries out the program on jump-landing technique. The full intervention program has a duration of three months and is performed 2 times a week during warm-up (5-10 min). Injuries are registered during the entire season.
\end{abstract}

Discussion: The results of this study can give valuable information on the effect of a coach supervised intervention program on jump-landing technique and injury occurrence. Results will become available in 2011.

Trial registration: Trial registration number: NTR2560

\section{Background}

Different studies have pointed out that injuries in jumplanding sports are of frequent occurrence [1-4]. In volleyball, gymnastics and basketball respectively, a total of 2.8 [CI 95\%: 2.0 -3.6], 2.2 [CI 95\%: $1.6-2.9$ ] and 9.8 [CI 95\%: 8.5 - 11.1] injuries per 1,000 exposure hours have been reported $[5,6]$. The majority of the injuries in these sports occur at the lower extremity, accounting for more than $60 \%$ of all injuries [2-4]. Both overuse (e.g. shin splints, stress fractures [7], patellar tendinopathy (PT) $[8,9]$, patellar femoral pain syndrome (PFPS)

\footnotetext{
* Correspondence: romain.meeusen@vub.ac.be

'Vrije Universiteit Brussel, Faculty of Physical Education and Physical Therapy, Department of Human Physiology and Sports Medicine, Brussels, Belgium Full list of author information is available at the end of the article
}

$[10,11]$ and acute injuries (e.g. ACL injury [12-14] and ankle sprains [15-17]) often occur in jump-landing sports.

Sports injuries often are accompanied by pain or other physical discomforts, which in turn result in use of healthcare resources and possibly also in absenteeism from work. The severity of sports injuries can be described based on different criteria including sporting time lost, permanent damage and cost [6]. In a study of Cumps et al. (2007) the number of basketball days for which the athlete was not able to play or train because of the injury sustained was set on 3 to 7 weeks [18]. This means that injury occurrence can put a stop to the athlete's participation in his sport for a long time. From the study of Cumps et al. (2008)[6] it also can be
C Biomed Central 
concluded that the direct medical and the indirect costs in Flanders involved in acute injuries only, are respectively $15,027,423 €$ and $111,420,813 €$. No information of the cost of overuse injuries was found, so it can be assumed that the actual cost of both acute and overuse injuries actually is much higher. Even more, important aspects of injury occurrence are the long term consequences. After, for example an ACL-injury or episodes of anterior knee pain, many athletes seem predisposed to osteoarthritis [19-21]. This can already occur at an early age and result in lifelong constraint in sport participation $[19,20]$. In order to reduce short and long term consequences, there is a need for sports injury prevention.

Arguably the most important injury mechanism for these lower extremity acute and overuse injuries is the jump-landing maneuver $[1,3,5]$. Proper jump-landing movement patterns are essential to absorb the generated impact forces efficiently, and are suggested to be strongly related to the athlete's risk for injuries to the lower extremity [22,23]. Consequently, various jump-landing related risk factors, such as increased knee valgus during jumplanding technique, ankle instability or a stiff landing technique, appear to be related with injury occurrence [8,24-26]. For example, a stiff landing strategy increases the risk of sustaining injuries due to higher ground reaction forces and decreased shock absorption during landing. Specific movement patterns such as dynamic valgus or stiff jump-landings technique can be a risk factor for respectively ACL injuries and PT [8,24,26,27].

With the relatively high rate of injuries of the lower extremity in jump-landing sports and the severity of these injuries, there is a need for practical preventive programs [28,29]. A program aiming at an improvement of jump-landing technique is potentially an important preventive measure while it is able to target a variety of risk factors for a variety of injuries. Previous attempts have been made to prevent specific injuries through improvement of jump-landing technique, e.g. recurrent ankle sprains [30] and ACL injuries [24]. However, most available prevention programs were supervised by sport physicians or physical therapists. This might work for (sub)elite sports were medical supervision is always available, but amateur sports lack the infrastructure and funds to have a sports physician or therapist permanently supervising such a program. Nevertheless, it is amateur sports where, in absolute sense, the injury burden is highest through high participation numbers. Therefore, the true effectiveness of available preventive programs in this important setting is questionable.

\section{Objective}

The objective of this randomized controlled trial is to evaluate the effectiveness of a coach supervised intervention program targeting jump-landing technique on the incidence of lower extremity injuries.

\section{Research questions}

- What is the effectiveness of a coach supervised jump landing intervention program on the incidence of acute and overuse injuries to the lower extremity?

- What is the effect of a coach supervised jump landing intervention program on jump landing technique of individual athletes?

\section{Methods}

The CONSORT statement was followed to describe the design of this study. This statement is a checklist intended to improve the quality of reports of randomized controlled trials [31].

\section{Study outline}

A two-way cluster randomized controlled trial with a follow-up period of one season (6 months) is used. The participation subjects are athletes from basketball teams of the national divisional, and, $1^{\text {st }}$ and $2^{\text {nd }}$ regional divisional basketball competitions.

The study protocol is accepted by the local ethical committee of the Free University Brussels (B.U.N. $\mathrm{B} 14320071963)$ and a trial registration number was requested (NTR2560).

This study is financially supported by the Flemish Government through the establishment of the Policy Research Center Sports, Youth and Culture.

\section{Participants}

Athletes who are actively participating in the national division and, $1^{\text {st }}$ and $2^{\text {nd }}$ regional basketball teams in Flanders, Belgium, are eligible for inclusion in the study. Athletes are excluded if they do not master the Dutch language or have a current injury to the lower extremity at time of inclusion.

Written informed consent is obtained from each athlete and the study is conducted in accordance with the ethical institutional rules for human research and in regulation with the Declaration of Helsinki for Medical Research involving human subjects.

\section{Sample size}

A power calculation is carried out for the main outcome variable lower extremity injury incidence. A difference of $50 \%$ in the incidence of lower extremity injuries between the intervention and control group after a follow up of one season is considered to be clinically relevant.

The prevalence of lower extremity injuries in basketball in Flanders being about $78 \%$ in one season [6], 34 subjects per group are needed to detect the intended difference of $50 \%$ in the incidence of lower extremity 
injuries, with a power of $90 \%$ and an alpha of $5 \%$. Assuming a dropout rate of about $20 \%$ a total of 82 athletes are needed to detect a potentially clinically relevant effect of the intervention. However, as teams serve as unit of randomization, a cluster effect should be taken into account. Therefore, an intra-cluster correlation coefficient of $20 \%$ was considered, resulting in a total of 240 athletes from 24 teams is necessary at baseline.

\section{Recruitment}

Of the 110 Flemish teams of the elite division, 24 teams are included and equally randomized to two study groups (Figure 1). Randomization and group allocation takes place before teams were contacted. This is done in order to avoid any spill over of the intervention while including teams. Through this method blinding of the teams to group allocation is secured.

\section{Intervention program}

After receiving informed consent and baseline questionnaire of a team's individual athletes, trainers are provided with a package that enclosed the necessary information. Control gorup (CG) trainers are provided with a DVD containing general information on the study. Trainers of the intervention teams receive a different DVD with general information on the study and specific information on the intervention program and the individual exercises. Also a written manual including the complete program and a detailed explanation for each individual exercise is provided.

Both research groups continue their regular training routine. Teams of the intervention group (IG) receive an additional intervention program to be carried out during the regular warm-up (Table 1). This program targets at improving the athletes' jump-landing technique.

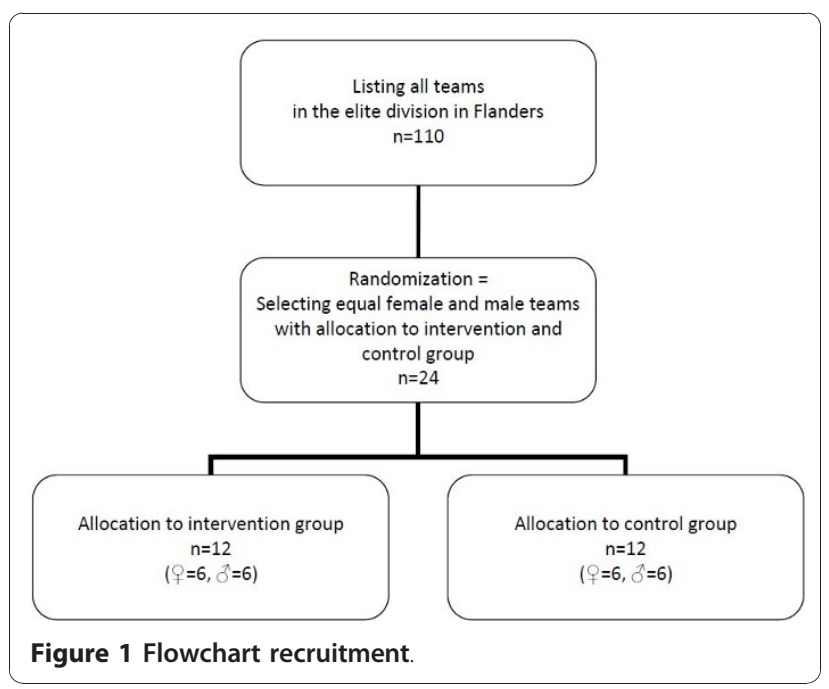

The program is a modification of two prevention programs previously proven to be effective for the prevention of lower extremity injuries [24,32]. The exercises in the current program are adapted so that a more progressive development is present. Furthermore, the materials required to complete the exercises are limited. The program has a duration of three months and is performed twice a week during warm-up (5-10 min). All exercises are selected so that the jump-landing program difficulty is gradually increased. First, basic techniques are practiced and then fundamental exercises are trained. Hereafter, more difficult and sport specific exercises are given in the performance phase. The intervention is considered to be appropriate for all athletes and to have no negative side-effects.

\section{Measurements}

During the study period there are two fixed measurements, at baseline (T0) and after 3 months (T1). At T0 a questionnaire is completed by the athletes, and at both occasions the athletes' jump landing technique is assessed. Additionally, exposure hours and lower extremity injuries are continuously registered during the entire 2010-2011 basketball season (6 months).

\section{Questionnaire}

At T0 all athletes complete a questionnaire on demographic data, previous injuries, sports history and current sports participation [33].

\section{Jump landing technique}

An improvement in jump-landing technique is determined by registering jump-landing technique of athletes in the CG and IG. Athletes are asked to perform 3 separate maximal vertical jumps which are recorded on camera (SONY HDV 1080i). The researchers collect the jump-landing data at T0 and T1. These jumps are all analyzed through the computer program Darttrainer ${ }^{\bullet}$. In addition, all jumps are evaluated through a predefined list of criteria, the JLS-System (Jump-landing Scorings system) (Table 2). This tool is developed as a field test to evaluate proper jump-landing technique.

\section{Exposure time}

Exposure is recorded by the coach on an exposure form. Coaches note the total duration of each training session and match, and classify the level of participation of each player (that is, in terms of full, three quarters, one half, one quarter, or no participation). If the player does not participate fully, the coach note the reason-that is, being injured, ill, or absent for other reasons. Completed exposure forms are returned on a weekly basis. Every week trainers are contacted by phone and urged to fill out the exposure sheets, and, if necessary, the injury forms. In this, we followed the example of Verhagen et al.[2] who applied the same method of exposure registration. 
Table 1 Overview of the jump-landing technique program

\begin{tabular}{|c|c|c|c|c|c|c|c|c|c|}
\hline $\begin{array}{l}2 \times / \text { week, } \\
10 \text { min. } \\
1 \text { min rest } \\
\text { between } \\
\text { repetitions }\end{array}$ & $\begin{array}{l}\text { Technique/ } \\
\text { Month } 1\end{array}$ & & & $\begin{array}{l}\text { Fundamentals/ } \\
\text { Month } 2\end{array}$ & & & $\begin{array}{l}\text { Performance/ } \\
\text { Month } 3\end{array}$ & & \\
\hline \multirow[t]{5}{*}{ Week 1} & Co-contractions & 10 & $\begin{array}{l}\mathrm{L}+ \\
\mathrm{R}\end{array}$ & Lying position & 15 & & X-Hops & 6 & $\begin{array}{l}\text { Cycles } L+ \\
R\end{array}$ \\
\hline & Wall Squat & 10 & & Pelvic bridge & 10 & $\mathrm{sec}$ & Hop-Hop-Hold & 8 & $L+R$ \\
\hline & Lateral Jump and Hold & 8 & $\begin{array}{l}\mathrm{L}+ \\
\mathrm{R}\end{array}$ & Repeated Tuck Jumps & 10 & $\begin{array}{l}\mathrm{L}+ \\
\mathrm{R}\end{array}$ & Mattress jumps & 30 & $\mathrm{sec}$ \\
\hline & Front Lunges & 10 & & Squat Jump & 10 & & Single leg $90^{\circ *}$ & 8 & $L+R$ \\
\hline & Step-Hold & 8 & $\begin{array}{l}\mathrm{L}+ \\
\mathrm{R}\end{array}$ & Jump Single Leg Hold & 8 & & Max Squat jumps-hold & 10 & $L+R$ \\
\hline \multirow[t]{5}{*}{ Week 2} & Co-contractions & 10 & $\begin{array}{l}\mathrm{L}+ \\
\mathrm{R}\end{array}$ & Pelvic Bridge Single Leg & 10 & & Crossover-Hop-Hop-Hold & 8 & $L+R$ \\
\hline & Squat & 10 & & $\begin{array}{l}\text { Prone Bridge Hip (EK) Shoulder } \\
\text { Flexion }\end{array}$ & 10 & $\begin{array}{l}\mathrm{L}+ \\
\mathrm{R}\end{array}$ & Single Leg 4 Way Hop-Hold* & 3 & $\begin{array}{l}\text { Cycles } L+ \\
R\end{array}$ \\
\hline & Step-Hold & 8 & $\begin{array}{l}\mathrm{L}+ \\
\mathrm{R}\end{array}$ & Side to Side Tuck Jump & 10 & $\mathrm{sec}$ & Single leg $90^{\circ}$ Ball* & 8 & $L+R$ \\
\hline & Walking Lunges & 10 & & Lateral Hop \& Hold & 8 & $\begin{array}{l}\mathrm{L}+ \\
\mathrm{R}\end{array}$ & $\begin{array}{l}\text { Step, jump up, down, vertical } \\
\text { jump }\end{array}$ & 5 & $L+R$ \\
\hline & Lateral Jump and Hold & 8 & $\begin{array}{l}\mathrm{L}+ \\
\mathrm{R}\end{array}$ & Hop \& Hold & 8 & & Max Squat jumps-hold & 10 & \\
\hline \multirow[t]{5}{*}{ Week 3} & Squat & 10 & & Single Leg Pelvic Bridge* & 10 & $\begin{array}{l}\mathrm{L}+ \\
\mathrm{R}\end{array}$ & $\begin{array}{l}\text { Single Leg } 4 \text { Way Hop-Hold } \\
\text { Ball** }\end{array}$ & 4 & $\begin{array}{l}\text { Cycles } L+ \\
R\end{array}$ \\
\hline & Lateral Jump and Hold & 8 & $\begin{array}{l}\mathrm{L}+ \\
\mathrm{R}\end{array}$ & Prone Bridge Hip extension & 10 & $\begin{array}{l}\mathrm{L}+ \\
\mathrm{R}\end{array}$ & Single Leg $180^{\circ}$ & 10 & $L+R$ \\
\hline & $\begin{array}{l}\text { Single Tuck Jump Soft } \\
\text { Landing }\end{array}$ & 10 & $\begin{array}{l}\mathrm{L}+ \\
\mathrm{R}\end{array}$ & Side to Side Tuck Jumps & 10 & $\begin{array}{l}\mathrm{L}+ \\
\mathrm{R}\end{array}$ & $\begin{array}{l}\text { Jump, Jump, Jump, vertical } \\
\text { jump }\end{array}$ & 10 & $\mathrm{sec}$ \\
\hline & Lunge Jumps & 10 & & Lateral Hops & 10 & $\mathrm{sec}$ & Mattress jumps & 40 & $L+R$ \\
\hline & Lateral Jumps & 10 & $\mathrm{sec}$ & Double leg $90^{\circ}$ & 8 & $\begin{array}{l}\mathrm{L}+ \\
\mathrm{R}\end{array}$ & $\begin{array}{l}\text { Running, Jump down } 1 \text { legged, } \\
\text { Jump }\end{array}$ & 8 & \\
\hline \multirow[t]{5}{*}{ Week 4} & Squat Jumps & 10 & & Single Leg Pelvic Bridge Ball & 10 & $\begin{array}{l}\mathrm{L}+ \\
\mathrm{R}\end{array}$ & Single Leg $180^{\circ}$ & 10 & $L+R$ \\
\hline & Lateral Jumps & 10 & $\mathrm{sec}$ & $\begin{array}{l}\text { Prone Bridge Hip Opposed Shoulder } \\
\text { Flexion }\end{array}$ & 10 & $\begin{array}{l}\mathrm{L}+ \\
\mathrm{R}\end{array}$ & $\begin{array}{l}\text { Jump, Jump, Jump, vertical } \\
\text { jump }\end{array}$ & 15 & $L+R$ \\
\hline & Double Tuck Jump & 8 & & Lateral Hops with ball & 10 & $\mathrm{sec}$ & $\begin{array}{l}\text { Running, Jump down } 1 \text { legged, } \\
\text { Jump }\end{array}$ & 10 & \\
\hline & Broad Jump & 10 & $\begin{array}{l}\mathrm{L}+ \\
\mathrm{R}\end{array}$ & Single Leg Lateral Hop-Hold & 5 & $\begin{array}{l}\mathrm{L}+ \\
\mathrm{R}\end{array}$ & Lay-up $\wedge$ & 10 & \\
\hline & Scissor Jumps & 8 & & Single leg $90^{\circ}$ & 8 & $\begin{array}{l}L+ \\
R\end{array}$ & Height jump ^ & 10 & \\
\hline
\end{tabular}

*Exercise on the mattress

$\wedge$ Sport specific jumps for basketball, can be adjusted depending on the sport.

\section{Injury definition}

To determine the effectiveness of the program for the prevention of injuries, all injuries that occur during the entire season are registered in both the IG and CG. Injuries are divided into two main categories: acute or overuse injuries. An acute injury is defined as a sports accident, with a sudden, direct cause/onset, which requires at least minimal (medical) care (e.g. ice or taping) and which causes the injured subject to miss out on at least 1 training session. Exclusion criteria involve muscle cramps and mild bruises. A subject sustains an overuse injury if he or she experiences a physical discomfort, with an insidious onset, that caused pain and/or stiffness of the musculoskeletal system, and that is present before, during and/or after the sports activity. The overuse injury is only registered if present for at least three consecutive sessions. Illness and fatigue are not registered as overuse injuries [18].

Injury registration

Coaches receive injury forms at the start of the study. In case of injury, the coach completes in concordance with the injured player injury registration forms, which have to be completed within one week after injury onset. On this form the player is asked to provide information on 
Table 2 Scorings system Jump-landing Technique (JLS-system)

\section{Front view}

(observers view)

\begin{tabular}{lll}
\hline Criteria & Description & Observation \\
\hline Maintaining 'balance' & Lifting one foot or toes of both feet due & Observe complete jump \\
- Loss of balance & to falling. &
\end{tabular}

Measurement Score

Maintaining 'balance'

to falling.

Loss of balance present or not

Loss of balance

not present or

doubt: 0

Loss of balance

present: 1

- Centre of gravity

At first foot contact:

displacement
Perpendicular through

incisura jugularis
At maximal knee flexion determine the position of incisura jugularis (left/right) compared to perpendicular
Displacement not present or doubt: 0

Displacement left or right: 1

Landing with 'both feet at the same time'

Simultaneous
Not simultaneous:

obviously 2 contact times of the feet visible
Observe complete jump

Simultaneous landing present or not landing present or doubt: 0 Simultaneous landing not present: 1

\begin{tabular}{ll}
\hline 'Muscular control' during & Presence of eccentric control during \\
landing & landing, capacity to lower the body in a \\
& controlled manner (no side movements of \\
& the knee, no sudden stops)
\end{tabular}

\begin{tabular}{ll}
\hline 'Genu varum' - 'Genu & Malalignement: \\
valgum' take-off & valgus or varus position
\end{tabular}

Observe complete jump (1)

Muscular control present or
not
Muscu

Muscular control present or doubt: 0 Muscular control not present: 1

\section{Perpendicular} through patella or doubt: 0 Patella lateral from the perpendicular: (1 = varum) Patella medial from the perpendicular: (2 = valgum)

\begin{tabular}{ll}
\hline 'Genu varum' - 'Genu & Malalignement: \\
valgum' landing & valgus or varus position
\end{tabular}
perpendicular from SIAS tO ankle (middl perpendicular goes through centre of patella
Perpendicular At maximal knee flexion: perpendicular from SIAS to ankle (middle of malleoli) - Landing perpendicular goes through centre of patella
No varum or valgum:

or doubt: 0

Patella lateral through patella from the perpendicular: (1 = varum) Patella medial from the perpendicular: (2 = valgum)

'Position of feet' Feet at shoulder width.

Perpendicular
At maximal knee flexion: Perpendicular trough centre of shoulders.
Perpendicular goes trough centre of malleolus internus and externus through centre of malleoli or doubt: 0 Perpendicular not through centre of malleoli: 1

\begin{tabular}{|c|c|c|c|c|}
\hline $\begin{array}{l}\text { 'Distance between knees' } \\
\text { compared between } \\
\text { initial contact and } \\
\text { maximal knee flexion }\end{array}$ & $\begin{array}{l}\text { Distance between knees at maximal knee } \\
\text { flexion, } 80-110 \% \text { of distance between } \\
\text { knees at initial contact. }\end{array}$ & $\begin{array}{l}\text { Distance between knees at } \\
\text { first foot contact and } \\
\text { distance between knees at } \\
\text { maximal knee flexion. }\end{array}$ & $\begin{array}{l}\text { Range of } 80 \%-110 \% \\
\text { difference. }\end{array}$ & $\begin{array}{l}\text { Between } 80 \%- \\
11 \%: 0 \\
\text { Not between } \\
80 \%-110 \%: 1\end{array}$ \\
\hline $\begin{array}{l}\text { Hyperpronation - } \\
\text { Hypersupination feet } \\
\text { Take-off }\end{array}$ & $\begin{array}{l}\text { Inside or outside movement of the } \\
\text { malleoli compared to starting position. }\end{array}$ & $\begin{array}{l}\text { Observe complete jump } \\
\text { - Takeoff }\end{array}$ & $\begin{array}{l}\text { Compare position feet with } \\
\text { starting position. }\end{array}$ & $\begin{array}{l}\text { Hyperpronation } \\
\text { or -supination } \\
\text { not present or } \\
\text { doubt: } 0 \\
\text { Hyperpronation } \\
\text { or supination } \\
\text { present: } 1\end{array}$ \\
\hline
\end{tabular}


Table 2: Scorings system Jump-landing Technique (JLS-system) (Continued)

\begin{tabular}{|c|c|c|c|c|}
\hline $\begin{array}{l}\text { Hyperpronation - } \\
\text { Hypersupination feet } \\
\text { landing }\end{array}$ & $\begin{array}{l}\text { Inside or outside movement of the } \\
\text { malleoli compared to starting position. }\end{array}$ & $\begin{array}{l}\text { Observe complete jump } \\
\text { - Landing }\end{array}$ & $\begin{array}{l}\text { Compare position feet with } \\
\text { starting position. }\end{array}$ & $\begin{array}{l}\text { Hyperpronation } \\
\text { or -supination } \\
\text { not present or } \\
\text { doubt: } 0 \\
\text { Hyperpronation } \\
\text { or supination } \\
\text { present: } 1\end{array}$ \\
\hline \multicolumn{5}{|l|}{$\begin{array}{l}\text { Side view } \\
\text { (right and left) }\end{array}$} \\
\hline Criteria & Description & Observation & Measurement & Score \\
\hline $\begin{array}{l}\text { Knee angle } \\
\text { - First foot contact } \\
\text { - Maximal knee flexion }\end{array}$ & & $\begin{array}{l}\text { Knee angle at first foot } \\
\text { contact } \\
\text { Knee angle at maximal } \\
\text { knee flexion }\end{array}$ & $\begin{array}{l}\text { Ankle between trochanter } \\
\text { major - caput fibulae (tractus } \\
\text { iliotibialis) - } \\
\text { mallolus externus }\end{array}$ & Degrees: \\
\hline $\begin{array}{l}\text { Hip angle } \\
\text { - First foot contact } \\
\text { - Maximal knee flexion }\end{array}$ & & $\begin{array}{l}\text { Knee angle at first foot } \\
\text { contact } \\
\text { Knee angle at maximal } \\
\text { knee flexion }\end{array}$ & $\begin{array}{l}\text { Angle between trunk - } \\
\text { trochanter major - caput } \\
\text { fibulae (tractus iliotibialis) }\end{array}$ & Degrees: \\
\hline $\begin{array}{l}\text { Ankle angle } \\
\text { - First foot contact } \\
\text { - Maximal knee flexion }\end{array}$ & & $\begin{array}{l}\text { Knee angle at first foot } \\
\text { contact } \\
\text { Knee angle at maximal } \\
\text { knee flexion }\end{array}$ & $\begin{array}{l}\text { Angle between caput fibulae } \\
\text { (tractus iliotibialis) - malleolus } \\
\text { externus - parallel with sole of } \\
\text { foot }\end{array}$ & Degrees: \\
\hline 'shoulders above knees' & & $\begin{array}{l}\text { Position at maximal knee } \\
\text { flexion }\end{array}$ & $\begin{array}{l}\text { Perpendicular through centre } \\
\text { of shoulder (humerus head) }\end{array}$ & $\begin{array}{l}\text { Perpendicular } \\
\text { through caput } \\
\text { fibula: } 0 \\
\text { Perpendicular } \\
\text { not through } \\
\text { caput fibula: } 1\end{array}$ \\
\hline $\begin{array}{l}\text { 'knees not further than } \\
\text { toes' }\end{array}$ & & $\begin{array}{l}\text { Position at maximal knee } \\
\text { flexion }\end{array}$ & $\begin{array}{l}\text { Perpendicular through centre } \\
\text { of knees }\end{array}$ & $\begin{array}{l}\text { Perpendicular } \\
\text { not further than } \\
\text { toes: } 0 \\
\text { Perpendicular } \\
\text { further than } \\
\text { toes: } 1\end{array}$ \\
\hline $\begin{array}{l}\text { 'forefoot landing and } \\
\text { rolling to heel' }\end{array}$ & Forefoot landing and rolling to heel & Observe complete jump & Pattern present or not & $\begin{array}{l}\text { Pattern present } \\
\text { or doubt: } 0 \\
\text { Pattern not } \\
\text { present: } 1\end{array}$ \\
\hline Arm swing & $\begin{array}{l}\text { Obvious arm swing that contributes to } \\
\text { the jump height }\end{array}$ & Observe complete jump & Arm swing present or not & $\begin{array}{l}\text { Arm swing } \\
\text { present: } 0 \\
\text { Arm swing not } \\
\text { present: } 1\end{array}$ \\
\hline
\end{tabular}

the injury location, injury type, diagnosis of the injury, direct cause of the injury, preventive measures used at the time of the injury, first aid given, and subsequent medical treatment. If an injury is noted on the exposure form and no injury registration form is received within two weeks after the injury is logged, the coach is contacted and urged to let the player complete the injury registration form.

\section{Process evaluation \& Compliance}

Coaches are contacted on a weekly basis by means of a telephone call. The goal of this call is to inquire about the ongoing of the study and to follow-up on any missing exposure or injury registration forms. In addition, IG coaches are asked whether they followed the prescribed exercises for that particular week. If not, the exercises that are carried are noted in order to gain insight into the compliance to the program.

At $\mathrm{T} 1$ coaches are required to complete a questionnaire inquiring on their opinion of the intervention program, their compliance to the prescribed exercises, and to inquire about any difficulties in executing the program.

\section{Statistical analyses}

The injury incidence density (IID) is calculated as the number of new injuries per 1,000 hours of participation, using exposure time of each individual participant until the first injury. The number of injuries divided by the total time at risk is the preferred measure of incidence because it can accommodate variations in the exposure time of individuals $[34,35]$. If an athlete suffers multiple 
injuries, only the first injury will be considered in the analysis.

Because the unit of allocation was teams, we perform a multilevel Cox proportional hazard regression analysis, using the computer based software SPSS 17.0 (SPSS Inc, Chicago, Illinois, USA), to estimate the hazard ratios (HRs) and 95\% confidence intervals (CIs). Teams will be used as cluster levels [36].

The difference between the CG and IG regarding the JLS-system is calculated using Repeated Measures ANOVA $(\mathrm{p}<0.05)$ for normally distributed data and the Mann-Whitney- $U$ test $(\mathrm{p}<0.05)$ for data which are not normally distributed.

\section{Implications of this study}

This study evaluates the effect of a coach supervised injury prevention program. If successful this will provide valuable information for sports injury prevention practice. As the majority of injuries are sustained in amateur sports where medical guidance is limited, effective coach supervised prevention has a great potential impact on public health.

\section{Acknowledgements}

This study was financially supported by the Flemish Government through the establishment of the Policy Research Center Sports, Youth and Culture. The authors have no conflicts of interest directly relevant to its contents.

\section{Author details}

'Vrije Universiteit Brussel, Faculty of Physical Education and Physical Therapy, Department of Human Physiology and Sports Medicine, Brussels, Belgium. ${ }^{2}$ EMGO Institute for Health and Care Research, Department of Public and Occupational Health. VU University Medical Center, Amsterdam, the Netherlands.

\section{Authors' contributions}

$I A, E C, E V$, RM were involved in the conception and design of the study. IA is involved in study data collection. All authors were involved in drafting the manuscript and revising it for critically important content. All authors have read and approved the final manuscript.

\section{Competing interests}

The authors declare that they have no competing interests.

Received: 19 October 2010 Accepted: 13 December 2010 Published: 13 December 2010

\section{References}

1. Ferretti A, Papandrea P, Conteduca F, Mariani PP: Knee ligament injuries in volleyball players. American Journal of Sports Medicine 1992, 20(2):203-207.

2. Verhagen $E$, Van der Beek A, Bouter L, Bahr R, Van Mechelen W: A one season prospective cohort study of volleyball injuries. Br J Sports Med 2004, 38(4):477-481.

3. Agel J, Olson DE, Dick R, Arendt EA, Marshall SW, Sikka RS: Descriptive epidemiology of collegiate women's basketball injuries: National Collegiate Athletic Association Injury Surveillance System, 1988-1989 through 2003-2004. J Athl Train 2007, 42(2):202-210.

4. Marshall SW, Covassin T, Dick R, Nassar LG, Agel J: Descriptive epidemiology of collegiate women's gymnastics injuries: National Collegiate Athletic Association Injury Surveillance System, 1988-1989 through 2003-2004. J Athl Train 2007, 42(2):234-240.

5. Harringe $M$, Renstrom $P$, Werner $S$ : Injury incidence, mechanism and diagnosis in top-level teamgym: a prospective study conducted over one season. Scandinavian Journal of Medicine \& Science in Sports 2007, 115-119.

6. Cumps $E$, Verhagen $E$, Annemans $L$, Meeusen R: Injury rate and socioeconomic costs resulting from sports injuries in Flanders: data derived from sports insurance statistics 2003. British Journal of Sports Medicine 2008, 42(9):767-772.

7. Chockley C: Ground reaction force comparison between jumps landing on the full foot and jumps landing en pointe in ballet dancers. J Dance Med Sci 2008, 12(1):5-8.

8. Bisseling RW, Hof AL, Bredeweg SW, Zwerver J, Mulder T: Relationship between landing strategy and patellar tendinopathy in volleyball. $\mathrm{Br} J$ Sports Med 2007, 41(7):e8.

9. Richards DP, Ajemian SV, Wiley JP, Zernicke RF: Knee joint dynamics predict patellar tendinitis in elite volleyball players. Am J Sports Med 1996, 24(5):676-683.

10. Duffey MJ, Martin DF, Cannon DW, Craven T, Messier SP: Etiologic factors associated with anterior knee pain in distance runners. Med Sci Sports Exerc 2000, 32(11):1825-1832.

11. Thomee R, Renstrom P, Karlsson J, Grimby G: Patellofemoral pain syndrome in young women. I. A clinical analysis of alignment, pain parameters, common symptoms and functional activity level. Scand J Med Sci Sports 1995, 5(4):237-244.

12. Malinzak RA, Colby SM, Kirkendall DT, Yu B, Garrett WE: A comparison of knee joint motion patterns between men and women in selected athletic tasks. Clinical Biomechanics 2001, 16(5):438-445.

13. Chappell JD, Creighton RA, Giuliani C, Yu B, Garrett WE: Kinematics and electromyography of landing preparation in vertical stop-jump - Risks for noncontact anterior cruciate ligament injury. American Journal of Sports Medicine 2007, 35(2):235-241.

14. Hughes $G$, Watkins J: A risk-factor model for anterior cruciate ligament injury. Sports Medicine 2006, 36(5):411-428.

15. Wikstrom EA, Powers ME, Tillman MD: Dynamic stabilization time after isokinetic and functional fatigue. Journal of Athletic Training 2004, 39(3):247-253.

16. Ross SE, Guskiewicz KM, Yu B: Single-leg jump-landing stabilization times in subjects with functionally unstable ankles. Journal of Athletic Training 2005, 40(4):298-304.

17. Verhagen $E$, van der Beek $A$, Twisk J, Bouter $L$, Bahr $R$, van Mechelen W: The effect of a proprioceptive balance board training program for the prevention of ankle sprains - A prospective controlled trial. American Journal of Sports Medicine 2004, 32(6):1385-1393.

18. Cumps $E$, Verhagen $E$, Meeusen R: Prospective epidemiological study of basketball injuries during one competitive season: Ankle sprains and overuse knee injuries. Journal of Sports Science and Medicine 2007, 6(2):204-211.

19. Lohmander LS, Ostenberg A, Englund M, Roos H: High prevalence of knee osteoarthritis, pain, and functional limitations in female soccer players twelve years after anterior cruciate ligament injury. Arthritis Rheum 2004, 50(10):3145-3152.

20. Hewett TE, Myer GD, Ford KR, Heidt RS Jr, Colosimo AJ, McLean SG, van den Bogert AJ, Paterno MV, Succop P: Biomechanical measures of neuromuscular control and valgus loading of the knee predict anterior cruciate ligament injury risk in female athletes: a prospective study. Am J Sports Med 2005, 33(4):492-501.

21. Thomas MJ, Wood L, Selfe J, Peat G: Anterior knee pain in younger adults as a precursor to subsequent patellofemoral osteoarthritis: a systematic review. BMC Musculoskeletal Disorders 2010, 11:201.

22. Bisseling RW, Hof AL, Bredeweg SW, Zwerver J, Mulder T: Are the take-off and landing phase dynamics of the volleyball spike jump related to patellar tendinopathy? British Journal of Sports Medicine 2008, 42(6):483-489.

23. Reeser JC, Verhagen E, Briner WW, Askeland TI, Bahr R: Strategies for the prevention of volleyball related injuries. British Journal of Sports Medicine 2006, 40(7):594-U520.

24. Hewett TE, Lindenfeld TN, Riccobene JV, Noyes FR: The effect of neuromuscular training on the incidence of knee injury in female athletes. A prospective study. Am J Sports Med 1999, 27(6):699-706.

25. Myer GD, Ford KR, Palumbo JP, Hewett TE: Neuromuscular training improves performance and lower-extremity biomechanics in female athletes. Journal of Strength and Conditioning Research 2005, 19(1):51-60

26. Caulfield BM, Garrett M: Functional instability of the ankle: Differences in patterns of ankle and knee movement prior to and post landing in a single leg jump. International Journal of Sports Medicine 2002, 23(1):64-68. 
27. Myer GD, Ford KR, Hewett TE: The effects of gender on quadriceps muscle activation strategies during a maneuver that mimics a high ACL injury risk position. J Electromyogr Kinesiol 2005, 15(2):181-189.

28. Parkkari J, Kujala UM, Kannus P: Is it possible to prevent sports injuries? Review of controlled clinical trials and recommendations for future work. Sports Med 2001, 31(14):985-995.

29. Harmer PA: Basketball injuries. Med Sport Sci 2005, 49:31-61.

30. Stasinopoulos D: Comparison of three preventive methods in order to reduce the incidence of ankle inversion sprains among female volleyball players. Br J Sports Med 2004, 38(2):182-185.

31. Schulz KF, Altman DG, Moher D, Grp C: CONSORT 2010 Statement: Updated guidelines for reporting parallel group randomised trials. Journal of Clinical Epidemiology 2010, 63(8):834-840.

32. Myer G, Chu D, Brent J, Hewett T: Trunk and hip control neuromuscular training for the prevention of knee joint injury. Clin Sports Med 2008, 27(3):425-448, ix

33. Knaepen $K$, Cumps E, Zinzen E, Meeusen R: Low-back problems in recreational self-contained underwater breathing apparatus divers: Prevalence and specific risk factors. Ergonomics 2009, 52(4):461-473.

34. Emery CA, Meeuwisse WH: Risk factors for injury in indoor compared with outdoor adolescent soccer. American Journal of Sports Medicine 2006, 34(10):1636-1642.

35. Emery CA: injury prevention and future research. Med Sports Sci 2005, 49:170-191.

36. Gutierrez RG: Parametric frailty and shared frailty survival models. Stata J 2002, 2:22-24.

\section{Pre-publication history}

The pre-publication history for this paper can be accessed here: http://www.biomedcentral.com/1471-2474/11/281/prepub

doi:10.1186/1471-2474-11-281

Cite this article as: Aerts et al:: Efficacy of a 3 month training program on the jump-landing technique in jump-landing sports. Design of a cluster randomized controlled trial. BMC Musculoskeletal Disorders 2010 $11: 281$

\section{Submit your next manuscript to BioMed Central and take full advantage of:}

- Convenient online submission

- Thorough peer review

- No space constraints or color figure charges

- Immediate publication on acceptance

- Inclusion in PubMed, CAS, Scopus and Google Scholar

- Research which is freely available for redistribution

Submit your manuscript at www.biomedcentral.com/submit 